\title{
İç Mimarlık Eğitiminde \\ Sözlü Tarih Yöntemi ve Belgelemeyi Bir Mekân Okuma, Yeniden Üretim Pratiği Olarak Değerlendirme
}

\author{
Güliz ÖKTEM TAŞDEMIR ${ }^{1}$
}

\section{Öz}

Bu çalışma, iç mimarlık eğitiminde egemen olan eğitim kalıplarının dışında kalan sözlü tarih yöntemini lisans düzeyindeki bir ders içeriğinde ele almayı hedeflemiş, uygulama örneğini ve çıktılarını kapsamına almıştır. Sözlü tarih yöntemi iç mimarlık eğitiminde ve alan literatüründe öncül örnekleri bu araştırmanın yazarı tarafından gerçekleştirilmiştir. Bu çalışmayla da birlikte, teori ve uygulama yönleriyle sözlü tarih yönteminin eğitime ve literatüre olan katma değerinin araştırılması ve tartışılması amaçlanmıştır. Çalışmanın ana amacı, iç mimarlık eğitimi içindeki ders içeriklerinde, yaratıcı düşünce sürecinin sosyo/mekânsal tarih üzerinden üretilen bir içerikle zenginleştirilmesidir. Böylelikle, sözlü tarih yönteminin kendisi, iç mimarlık eğitimi içinde alternatif bir araç olarak ele alınmıştır. Araştırma, Başkent Üniversitesi, İç Mimarlık ve Çevre Tasarımı Bölümü'nde 2018-2019 Güz Dönemi'nde eğitimini sürdürmekte olan otuz, dördüncü sınıf lisans öğrencisi ile yürütülmüş, on dört haftalık bir araştırma, üretim sürecini içermiştir Çalışmanın yönteminde karma yöntem yer almıştır. Bu bağlamda üç ana aşama makalenin araştırma stratejisinde, veri değerlendirme aşamasında yer almış, haftalık olarak da ders işleniş metodunda takip edilmiştir. Sırasıyla, sözlü tarih yönteminin kendisi ve araçlarının öğrencilere tanıtılması, tarihsel referans aracılığıyla imgelem ve kuramsal tartışma temelli temsilin üretilmesi bu ders kapsamında gerçekleştirilmiştir. Araştırmanın bağlamsal sınırı yürütücü tarafından belirlenmiş Ankara, Etimesgut merkezli bir çalışma alanı öğrencilerin araştırma sahasını oluşturmuştur. Yaratıcı sürecin kendisinde tasarlama eylemi bu yazının temelinde yer alan eğitim sürecindeki öğrenci grubunun toplumsal yapı ile temasını sağlamış, kentsel/kamusal yaşantı gözlemini, mekânsal irdelemelerinin bütününü bir kültürel arkaplanla sunmuştur. Bu kapsamda da sözlü tarih yöntemi ve belgeleme, alanlar arası ilişkilerin temasını arttırmayı hedefine alan bir eleştirel platform olarak çalışmaya katkı sağlamıştır. Dersin çıktıları ve saha araştırmasının verileri ele alındığında, sözlü tarih yönteminin iç mimarlık eğitiminin içeriğine dâhil olması, yaratıcı düşünce biçimini desteklemiş, mekânsal farkındalığı arttırmış, bilginin kaynağını arama, bilgiyi üretme ve paylaşma anlamında bilinç düzeyini etkilemiş, gerçek yaşam bağlantısı sağlayarak öğrencileri çok yönlü düşünmeye teşvik etmiştir. Yapı kabuğunun ötesinde mekânsal tarih, değişen ve yenilenen anlamda tartışılabilmiş, yeni yaklaşımları oluşturabilmek konusunda potansiyel barındırmıştır. Sonuç olarak, mekânsal tarihin farklılaşan metotlar aracılığıyla çalışılma gereksinimi ve bu gereksinimin lisans düzeyindeki bir deneysel içerikle gerçekleştirilmesi literatüre yeni bir araştırma alanı sunabilir, ilerleyen çalışmalar için bir altıı oluşturabilir.

Anahtar Kelimeler: ļ̧̇ Mimarlık Eğitimi, Sözlü Tarih, Mekânsal Tarih, Belgeleme, Yeniden Üretim

\footnotetext{
${ }^{1}$ Başkent Üniversitesi, Güzel Sanatlar, Tasarım ve Mimarlık Fakültesi, İç Mimarlık ve Çevre Tasarımı Bölümü, Ankara. İlgili Yazar/Corresponding author: gulizoktem@gmail.com
} 


\title{
Reading Oral History Method and Documentation in Interior Architecture Education as a Space Evaluation and Re-Production Practice
}

\begin{abstract}
This study aimed to deal with the oral history method, which is outside the dominant educational patterns in interior architecture education, in a course content at the undergraduate level, and included the application example and its outputs. Preliminary examples of oral history methodology in interior architecture education and field literature were carried out by the author of this research. With this study, it is aimed to investigate and discuss the added value of the oral history method to education and literature in terms of theory and practice. The main purpose of the study is to enrich the creative thinking process with a content produced through socio / spatial history in the course contents within interior architecture education. Thus, the oral history method itself has been considered as an alternative tool in interior architecture education. The research was carried out with thirty, fourth-year undergraduate students who were continuing their education in the Department of Interior Architecture and Environmental Design in Başkent University, Department of Interior Architecture and Environmental Design in 2018-2019 Fall Semester, and a fourteen-week research included the production process. The method of the study included mixed methodology. In this context, three main stages were included in the research strategy of the article, in the data evaluation stage, and were followed weekly in the teaching method. Introducing the oral history method itself and its tools to the students, and the production of representation based on imagination and theoretical argument through historical reference, respectively, were carried out in this course. The contextual boundary of the study was determined by the director, and a study area centered in Ankara, Etimesgut formed the research area of the students. The act of designing in the creative process itself has provided the contact of the student group in the educational process, which is the basis of this article, with the social structure, and presented the observation of urban / public life and the whole of its spatial investigations with a cultural background. In this context, the method of oral history and documentation contributed to the study as a critical platform aiming to increase the theme of inter-domain relations. Considering the results of the course and the data of the field research, the inclusion of the oral history method in the content of interior architecture education has supported the creative way of thinking, increased spatial awareness, influenced the level of consciousness in terms of searching for the source of information, producing and sharing information, and encouraging students to think multi-faceted. has done. Beyond the building shell, spatial history could be discussed in terms of changing and renewal, and it has the potential to create new approaches. As a result, the need to study spatial history through differentiating methods and the realization of this requirement with an experimental content at the undergraduate level can present a new research area to the literature and form a basis for future studies.
\end{abstract}

Keywords: Interior Architecture Education, Oral History, Spatial History, Documentation, Re-production 


\section{Giriş}

Tasarlama eyleminin kendisi bilginin üretiminde, öznel olan bilginin oluşturulması anlamında yaratıcı bir süreç olarak var olmaktadır. Ancak bu çalışmanın gündeminde yer alan hedef, kanıksanan eğitim modelinde alternatif bir bakışla çalışma alanlarının gerçekleştirilebileceği savını tartışmaya açmayı hedeflemektedir. İç mimarlık eğitiminde tasarlama eyleminin bütününe etki edecek alternatif bir öğrenme aracı olarak sözlü tarih yöntemini ve saha araştırmasını pratiğine almaktadır.

İç mimarlık eğitiminde 'saha araştırması', uygulamalı ve teorik içeriğe yön veren bir metodoloji olarak özellikle atölye temelli derslerin öncül girdilerini oluşturan 'belgeleme' aşamasını içermektedir. Ancak yapısal belgelemeler, gerçek yaşam verilerini ve arkaplan ilişkilerini, arındırılmış bir biçimde öğrenciye sunarken yönlendirilmiş bir içerik tanımlamaktadır. İç mekânın kendisi ise, kentsel mekânın uzantısı olarak çalışan, doğrudan ilintili anlamlılık durumlarını içeren karmaşık bir şemanın parçası olarak ifade bulabilir. Bu bağlamda araştırmanın ana okumasında yer alan mekân ve alt anlamları, özneleriyle birlikte, güncel veya geçmiş zaman diliminin değerlendirilmesi sürecini içermektedir. Böylelikle tasarlama eyleminde yaratıcı düşünce biçimini, düşünsel olarak çeşitlendiren bir yeniden üretim aşamasına yönlendirmektedir.

Yeniden üretim aşamasının kendisi bu araştırmada iç mekânın ve bileşenlerinin 'izini sürmek', mekân üretimi pratiği üzerine hâkimiyet alanlarını tartışmak bağlamında iki teori üzerinden değerlendirilir. Bu anlamda araştırma teorik arka planını Walter Benjamin aracılığıyla 'domestik' olanının 'kentsel iç mekâna' aktarımından ve Henri Lefebvre'nin, sosyal mekânın üretimi ve Paul Freire'nin 'Özgürleştirici Eğitim Modeli' üzerinden temellendirilmektedir. Benjamin'e göre arındırılmış temsil dilini dönüştürme potansiyeli bulunan kentin nesneleri tüketim öğelerine dönüşmektedir (Rice, C., 2007, s.9-10). Böylelikle kentin nesnesi olan mekân da yeni bir doğa üretmeye ve kendi sosyal ilişkilerini başlatma potansiyelini edinmektedir. Mekânın kullanıcıları ve öğrenme sürecindeki öğrencilerin buradaki sosyal ilişkiler ağının bir parçası olması, altyapı ve üstyapı ilişkilerinin ortaklaşa düşünsel sürecini/sonucunu içeren yaratıcı bir sürece işaret etmektedir (Marx; Fernbach; 1991, s.225-240). Bu bağlamda, toplumun entelektüel üretimi ve birikimi, bu araştırmanın kapsamındaki örnek incelemenin aracı olan ders işleniş metodunda, tarihsel bağlantılarından bağımsız olmayan bir düşünsel arayışı değerlendirmiştir. Henri Lefebvre ise, mekânın üretimi konusunda devlet ve sermayenin etken varoluşuna dikkat çeker, böylece homojenleşen bir etkenlik alanı oluşturulduğunu ifade etmektedir (Lefebvre, 1991, s.52-60).

$\mathrm{Bu}$ yönlendirici etki alanının kendisi, eğitim içeriklerinde de sınırlayıcı bir yaklaşım ve 'dikte edilen bir ifade biçimi' olarak kendisini görünür kılabilir. Özellikle, Paul Freire'nin Ezilenlerin Pedagojisi kitabında yer alan öğrenci ve öğreten ilişkisi bu teorik çerçeveyle birlikte bu araştırmaya yön vermektedir. Freire'nin öğrenme eylemindeki sınırlılıklar bu etkenlik alanları ile örtüşmekte, Lefebvre'nin kentsel egemenlik alanlarının inşası konusunda örtüşen bir görüş birlikteliğini içermektedir. Buna göre, öğrenci ve öğreten kişi arasındaki monolog/diyalog durumu, çoğul seslilik barındırmaz ise mekânın tekil yönden incelenmesi mümkün olabilir. Bu durum da eğitim olanaklarındaki arındırılmış bakışı tanımlayabilir. Böylelikle yürütücü görüşü de tekil görüş içerme potansiyeli bulunan, öğrenme faaliyetinde de 'sunulan' bir kabulü oluşturabilir (Freire, P., 2008, s.54-60).

$\mathrm{Bu}$ araştırmanın amacı iç mimarlık eğitimindeki belirtilen olası kabulleri, perspektifini ve sonuç hedefli yaklaşımlarını dönüştürme potansiyeli bulunduran yeni bir yöntemle sorgulamaktadır. Böylelikle de alternatif üretim biçimlerini değerlendirmeye açmaktadır. 
Araştırmanın literatüre olan katkısı yöntem ve yapısal inceleme ışığında çoğul yönlüdür. Çoğul yönelim kapsamında, iç mekânların tarih yazımı içinde aktarıla gelmeyen, eğitim sistemi içerisinde de yer almayan bir bakışla incelemesi öğrenciler aracılığıyla, yöntemin üretimi ve paylaşııması da yürütücü tarafından alana katkı sunacaktır.

$\mathrm{Bu}$ yaklaşımdan hareketle dersin işleniş kurgusu, iç mimarlık eğitiminin pratiğine, ayrışan üretim biçimleri, yöntemleri üzerinden üç temel grup dâhilinde incelenmiştir (Angélil, 2003, s.29). Üç temel grup sırasıyla metodun araçlarını tanıma, kuramsal tartışma temelli üretim, sezgiye dayalı imgelem üretimi olarak çalışmanın iç mimarlık eğitim alanı içinde yer alan teori ve uygulamalı yönü ilişkilendirmiştir.

\section{Yöntem | Araştırmanın Tasarımı}

Çalışmanın yöntemi, yazar tarafından geliştirilen literatürde örneği bulunmayan özgün bir yaklaşımı içermektedir. Bu kapsamda ders işleniş yöntemiyle paralel bir yaklaşımda ilerleyen nitel araştırma metodolojisi üç ana kuramsal yaklaşımdan temellenmektedir. Araştırmanın yer aldığı ders, on dört hafta ve haftada üç saat süreli, otuz bir öğrenci katılımı ile gerçekleştirilmiştir. Ders strüktürel olarak üç aşamalı olarak değerlendirilmiş ve yöntemi, teorik altyapısı yaratıcı düşüncenin üretim biçimlerini geliştirmeyi hedeflemiştir.

Teorik altyapıda bağlamla ilişki birincil olarak, 'kentin izlerini aramak' ve kentlilerin sözel tanıklıklarına başvurmak üzerinden kurulmaktadır. Walter Benjamin, kenti domestik bir ilişkiyle ele alır. Bu anlamda kentin özneleri, kent içinde kendilerini evsel mekânda hisseden deneyimleyiciler olarak özel alan deneyimi yaratarak onun zamansallığını sürdürmektedirler (Rice,C., 2007, s.19-35). Özel alan deneyimi ise kentlilerden bağlam alan sözel tanıklıkların sözel kaynakları oluşturması anlamında çalışmanın altyapısını zenginleştirmektedir. Böylelikle belirli toplulukların veri anlamında sağlamakta olduğu kaynak, tarih yazımını değiştirme (Perks, Robert, and Alistair Thomson, 2016, s.14), dönüştürme gücü bulunan bir alanı işaret etmektedir.

İkincil olarak Henri Lefebvre'nin mekânın üretimi, ekonomi-politik ${ }^{2}$ bir bakışla mekânözneleri ve mekânın üreticilerini kuramsal olarak sorgulamaktadır. Lefebvre'ye göre, kent ve kentsel mekânın ana üreticileri, ekonomi-politik alanla ilişkilenen kamu-erkidir. Buna göre sosyal mekânın üretimi neo-liberal etkenlerle bağlantılıdır (Lefebvre, H., 1991, s.58). Bu kapsamda araştırmada sosyo-mekansal araştırmanın kaynağı ve gerekçesi olarak teorik altyapıda yer almaktadır.

Üçüncül gündem Paul Freire'nin bireyi eğitim aracılığıyla özgürleşmesi idesi, 'problem tanımlayıcı eğitim modeli' bu çalışmaya yön vererek 'sözlü tarih metodolojisini' örnek çalışma olan dersin işleniş yöntemine entegre etmiştir. Freire'ye göre, "özgürleşme praksis'tir"; böylece eleştirel bir gözle nesneyi irdeleme, eyleme geçme eğitimin özgürleştirici yanını ortaya çıkaracaktır (Freire, P., 2014, s.56). Bu bağlamda yukarıda belirtilen üç teorik altyapı kapsamında dersin işleniş metodu eşleştirilmiş, dinamik ve aşamalı bir uygulama süreci yer almıştır. Uygulama sürecindeki dinamizm, katılımcı öğrenci grubunun 'grup dinamiği' bağlamında değerlendirilmiş, süreçle eşzamanlı olarak yürütücüye içerik, süre, çalışma konularında geribildirim sağlamış, bu kapsamda eklemeler, çıkarmalar gerçekleştirilmiştir.

\footnotetext{
${ }^{2}$ Detaylı Okuma İçin Lütfen Bakınız: Marx, Karl. Economic and Philosophic Manuscripts of 1844. Moscow: Progress Publishers, 1982.

${ }^{3}$ Detaylı Okuma İçin Lütfen Bakınız: Güven Arif Sargın, Toplumbilim Açısından Mimari Praxis: Mimarlığın Öteki Ayraçları Üzerine Düşünceler. "Mimarlık", (2005), s.22-25.
} 
Uygulama adımlarında kentin izlerini sürme eylemi, metodun araçlarının tanıtılması, tartışııması, belgenin üretilmesi, saha çalışması süreci izlemiştir. Sosyal mekânın üretimi üzerinden kenti ve mekânlarını okuma gündemine ise sahadan elde edilen veriler aracılığıyla üretilen bir imgelem, temsil oluşturulması beklenmiştir. Üçüncül aşamada ise bütüncül bir yaklaşımla, özgürleştirici praksise bağlı kuram temelli üretim beklenmiş, verilerin değerlendirilmesi sağlanmıştır (Tablo 1).

Tablo 1. Araştırma Yönteminin Tasarımı, Şematik Aktarım; (Güliz Öktem Taşdemir Arşivi)

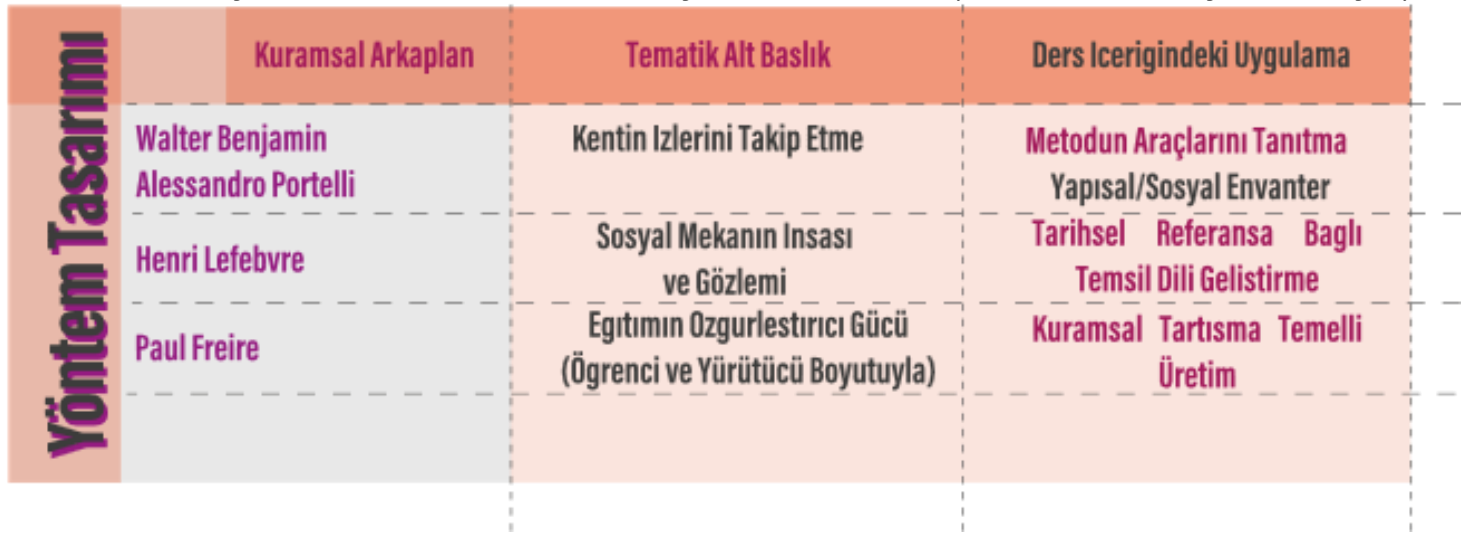

Öğrencilerin, fiziksel ve algısal olarak ilişik kurmakta olduğu saha araştırması, yapılı çevre gözlemi, belgeleme (fotoğraf çekme, eskiz üretimi) ve belge temini (resmi ve resmi olmayan belgeleme, yerel yönetim kaynaklarının değerlendirilmesi), sözlü tanıklığa başvurma aşamaları yukarıda belirtilen süreç içinde bu değerlendirmenin aşamalarını tanımlamıştır. Böylelikle tarihsel referansların değerlendirilmeye alınmakta olduğu kısa süreli problem tanımı ile bağlam değerlendirmesi, iki boyutlu anlam/kavram üretimi ve temsilini üretme, kamu ile paylaşılacak olan iki boyutlu temsil dili üretme öğrencilerin yükümlülükleri arasında yer almıştır. Öğrenciler bütüncül süreç içinde sürekli olarak tarihsel ve sosyal referansları yeniden düşünmeye davet edilmiştir.

\section{1 Çalışmanın Katılımcıları}

Çalışma otuz bir öğrenci ile gerçekleştirilmiştir. Başkent Üniversitesi, Güzel Sanatlar Tasarım ve Mimarlık Fakültesi, İç Mimarlık ve Çevre Tasarımı Bölümü'nde, 2018-2019 Güz Dönemi'nde yürütülen seçimlik ders ${ }^{4}$ akış şeması yaratıcı düşünceyi tetikleyici üç aşama üzerinden temellendirilmiştir.

Çalışmanın katıımcıları ise saha araştırması kapsamında yirmi kişi ile yarı yapılandırılmış görüşme gerçekleştirmiştir. Bu aşamada görüşmeciler anlatı araştırması alt başlığında özgün hikâyelerini anlatmıştır. Yaşam-tabanlı anlatılar (Creswell, J.2013, s.121-140), on dört erkek ve altı kadın görüşmeci ile sürdürülmüş, kişilerin bireysel referansları ile görüşmeciler tespit edilmiştir. Otobiyografik karakterli görüşmeler (Nevins, A.,1967, s.35-s52) gruplamalarla çoğul bellek üzerinden okunabilen mekânsal, olay esaslı hatırlamaları içermiştir. Mekânsal hafıza öğeleri öğrenciler tarafından oluşturulan çoğul katılımcılı çalışma grupları aracııı̆ıyla belirtilen yöntem kapsamda irdelenmiştir.

\footnotetext{
${ }^{4}$ Yakın Çevrenin Işslevlendirilmesi adlı ders, 3. Sanat ve Tasarım Eğitimi Sempozyumu ve Çalıştayı "Dijital Çağda Sanat ve Tasarım" teması altında yürütücü tarafından kurgulanan içerik ile değerlendirilmiş, dersin çıktıları sergilenmiştir. Detaylı içerik okumasına ilişkin bkz. Küçüktaşdemir, G., Dijital Çağda Kent Pazarlarını Yeniden Düşünmek Çalıştay Kitabı, Kent Belleğinde Etimesgut ve Gündeliğin Mekânları, s.60-71, 2018. ISBN: 978-605-68615-5-0, Mim İç ve Dış Mekân Baskı Sistemleri Reklam Matbaacılık Tic. Ltd. Şti.
} 
Saha araştırması içeriğine ilişkin yarı yapılandırılmış görüşme, soru-cevap yapılandırması öğrenciler ve yürütücü birlikteliğinde gerçekleştirilmiş, pilot görüşme gerçekleştirilerek sorular yenilenmiştir. Soruların kapsamı 1950-1980 yılları arası, Ankara'da Etimesgut Bölgesi'nde gündelik yaşamın mekânlarını ele alan bir içerikle ele alınmıştır.

\subsection{Veri Toplama Araçları}

Veri toplama araçları ders kapsamında teorik arkaplan ilişkisinde de aktarıldığı üzere kentin yapısal incelemeyle envanter oluşturma aşamasını kapsamaktadır. Bu bağlamda saha araştırması yeri görme, belgeleme ve belge temin etme, sözlü tanıklığa başvurma, anlam/kavram üretimi ile iki boyutlu üretim, tarihsel arka plan ve belge temini/belgeleme ile iki boyutlu üretim aşamalarını içermiştir. Böylelikle bu dersin çıktıları aracılığıyla, kapital yoğunluğa bağlı sermaye, saha araştırması katkısıyla 'iş gücü', 'malzeme', 'düşünce' üretmekte olan eğitsel biçimlenmenin yapısını değiştirmeyi ve neo-liberal yapının 'arzu nesnesi' olan üretim biçimlerinin potansiyel dönüşümünü alt okumalar aracılığıyla desteklemeyi hedeflemiştir.

Veri toplama aracı çalışmada katılımcılarını 'odak grup' olarak ele almıştır. Bağlama ilişkin on ucu açık soru yöneltilmiş, katılımcıların kendi aktarımları ile gündelik yaşam ölçütleri ve mekânları, anma sıklıkları ortaya çıkarılmıştır. Çalışmaya katılan yirmi gönüllü görüşmeci, farklı meslek dallarında veya ücretsiz ev işçisi olarak görev almıştır. Yaş ortalaması ise yetmiş yaşı geçkin olan grubun çalışma dönemi gereği aktif kentliler olması konusu üzerinde durulmuştur. Bu anlamda öğrenciler, veri toplama aşamasında özellikle sözlü tarih pratiğinde birer 'kolaylaştırıcı' konumunda yer almış ve grup görüşmelerini, kamusal mekânda izin dâhilinde gerçekleştirmiştir. Grup dinamiğine bağlı yorumlamalarda özel kategoriler oluşturularak görüşmeci belleğinde en sık anılan eylem/mekânlar tespit edilmiş, yeniden üretim pratiği bu tespit üzerinden oluşturulmuştur (Kitzinger, 1994, s.5.-10).

Tablo 2. Dersin İşleniş Yöntemine İlişkin Şematik Aktarım, (Güliz Öktem Taşdemir Arşivi)

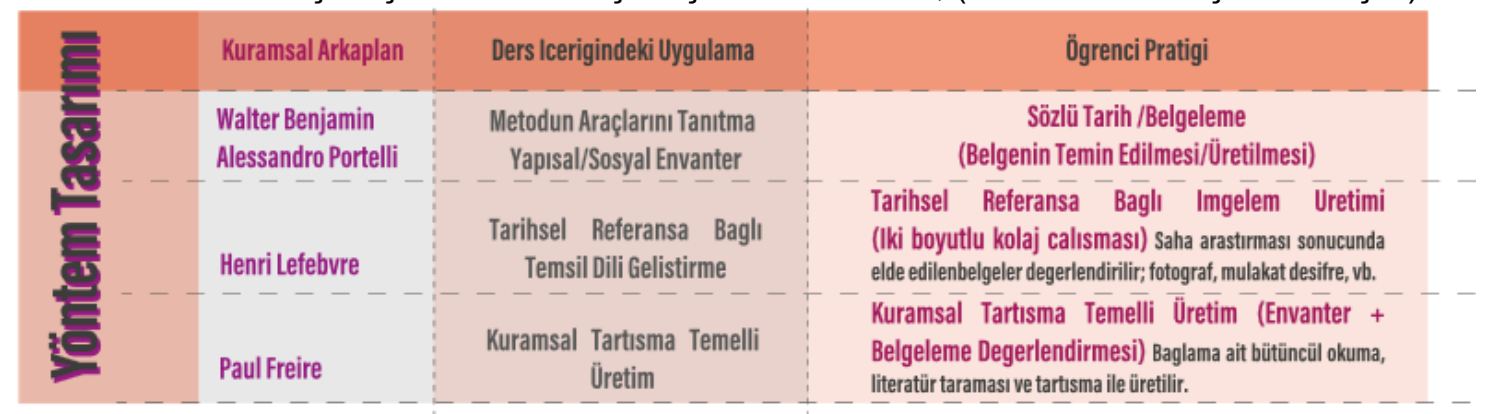

\subsection{Metodun Araçlarını Tanıma}

Walter Benjamin'e göre iç mekân ve yaşam deneyiminin kendisi, zamansız kılınan bir kimlik öğesi olarak mekânın özneleri tarafından üretilir. Böylelikle bu yazının merkezinde yer alan yaratıcı eylem ve metodu içinde yer alan sözlü tarih, zamansız kılınan deneyimlerin bütününü belgelemek amacı taşımaktadır. Bu araştırmanın gündemini oluşturan dersin strüktürel niteliği, sosyal mekânın inşası, yer ile ilişkili olma durumunu ve ayrışan kuramsal yaklaşımları, kavram ve belge üretimi boyutuyla birlikte ortak amaç olarak ele almıştır. Bu ortaklaşan amacın olası katkıları, mekânın çoklu verisini değerlendirmeyi ve 'herkese ait olanın' mekânını aramayı desteklemektedir (Arendt, H. ,1998, s.254). Tarihsel referanslar, mekânın kendisini bir 'inceleme nesnesi' haline getirirken, kullanıcılarını ve tasarlayanları çerçevesi içine almaktadır 
(Ed. Weinthal, Lois, 2011, Colomina, s.482). Bu çerçevenin kendisi de bir öğrenme aracı olarak sözlü tarihin verilerini oluşturarak yaratıcı sürecin önünü açacak, sözlü tarihin aktörlerini etken bir katılımcılığa, katılımcı yaratıcılığa yönlendirecektir. İç mimarlık eğitimi için belirtilen uygulamalar bu anlamda ölçeği değişen yaklaşım ve teknikler ile ele alınabileceği gibi, çalışma sözlü tarih metodolojisini bu uygulamaların bütüncül yaklaşımı için bir araç olarak kullanmaktadır.

Sözlü tarih metodolojisi, 'kişisel ve tarihi', 'kişisel ve nesiller' arasındaki bağlantıyı sosyal içerik ile inşa eden ve kişilerin öz yaşantısını bu yolla biçimlendirdiği bir veri analojisi sağlamaktadır. Bu metodolojinin mekân tasarımındaki aktivist etkisi toplumsal ölçüde tanık olunan olay temelli hatırlamalar aracılığıyla güncel/geçmiş bellek çalışmalarını mekânla ilişkilendirmektedir (Ed. Perks, R.\& Thomson, A.; Hirsch, 1998, s.214-223). Sözlü tarih yönteminin ana hedefi tarih yazımında yer almayan ve hatta aktarılmayanları sorgulanabilir kılmaktır (Thompson, P., 1988, s.77-86).

Bu bağlamda, dersin ilk üç haftalık bölümünde yönteme ilişkin bilgi aktarımında bulunulmuş, öğrencilerden çalışma grupları oluşturması beklenmiştir. Bunu takiben öğrencilerle birlikte saha gezisi gerçekleştirilmiş ve öğrencilerden potansiyel çalışma konularını saptamaları beklenmiştir. Potansiyel konu seçimi, kentsel mekâna ait açık/kapalı olabileceği gibi, özelleşmiş işlevlere yönelik, kamu erkine ve kamuya ait deneyime uygun olabileceği belirtilmiştir. Bu veriler ile Etimesgut'un Ankara bağlamında gelişimi aktarılmıştır. Öğrencilere çalışma alanının dönemi konusunda kısıt getirilmiş, Erken Cumhuriyet Dönemi veya Orta Yüzyıl Modernizmi'ne ait yapı stokundan araştırma alanlarını belirlemeleri beklenmiştir. Bunu takip eden yaklaşımda öğrenciler, ön araştırma ve sözlü tanıklık görüşmelerini gerçekleştirebilmek için soru yapılandırması sürecini tamamlamıştır. Oluşturulan sorular, yürütücüyle birlikte tartışılmış, pilot bir görüşme gerçekleştirilmiştir. Yapısal inceleme ile döküm oluşturma bu anlamda araştırmanın kaynağını aramak/üretmek bağlamında önem taşımıştır. Böylece bilginin ana üretim kaynağı olan öğrenme deneyiminin kendisinde problem tanımı, katmanlı yapıda görünürlük kazanmaya başlama olanağı bulunan kültürel arka planı görme ve okuma eylemi dâhilinde, hatırlama, tartışma süreçlerini oluşturmuştur. Böylece sentez sürecinde çalışmanın metodolojik yaklaşımı, dilsel aktarım paralelliğinde hafızayı tetikleyerek, kişisel ve kolektif hafızayı, geçmiş ve gelecek ara kesitindeki deneyim bütünlüğü olarak sunmuş, öğrencilerin bu aşamada diyalog kurma bilinci pekişmiştir.

Öğrencilerle sözlü tarih yöntemi aracının yarı yapılandırılmış mülakatlar için hazırlanan sorular ve stratejiler 'tematik analiz' (Riessman, Catherine K., 1993, s.1-7) kapsamında hazırlanmıştır. Tematik bilgiler ışığında bölgede kullanımı yoğunlaşan mekânlar öğrenciler tarafından yeniden üretimin bir parçasını oluşturmaktadır. Bu bağlamda sözlü tarih çalışmasına katılım gösteren gönüllülere öz yaşam bilgileri, Etimesgut'ta ikamet ettiği bölge veya alt bölgeler sorulmuş, gündelik yaşamda çoklu yönden kullanımda olan mekânsal oluşumlar ve anlam durumlarını aktarması beklenmiştir. Sosyal temas ile öğrenme örneğinde, öğrencilerin meslek pratiği dışındaki kişiler ile görüşme gerçekleştirebilmesi sağlanmış, iç mekân bileşenlerinin yanı sıra gerçek yaşantı ara kesitinden aktörlerle teması mümkün olmuştur. Bu anlamda sözlü tarih metodolojisi zamansız bir mekânsallığın verisini oluşturabileceği gibi toplum ve bireysel teması, mesleki platformun eğitsel ayağında yoğunlaştırmıştır. Belgelemenin görsel ve yazılı olarak iki adımlı yaklaşımında resmi ve resmi olmayan belgelere başvurma, alternatif olan tarihsel aktarıma ulaşma hedefiyle birlikte ele alınmıştır. 


\section{Tarihsel Referansa Bağlı İmgelem Üretimi}

Belge üretimi ve kent/kentli izlerini birer veri olarak değerlendirmekte olan öğrencilerle, tarihsel referanslarına bağlı imgelem üretimine ilişkin bilgi aktarılmıştır. Bu fazda öğrenciler, bir haftalık ders zaman diliminde, elde edilen verilerle mekân temsilinin yeniden üretimini gerçekleştirmesi konusunda bilgilendirilmiştir. Elde edilen veriler, yapı grupları, kullanıcı tarifleri ve deşifre çalışmaları yenilenmiş, süreli problem tanımı oluşturulmuştur. Öğrencilerin ana yöntemi ise sözlü tanıklık kapsamında gerçekleştirilen tematik analizin bir paçası olmuştur. Bu kapsamda görüşmeci ve görüşmeci belleği üzerinden saptanan mekânsal hafızaya ilişkin üretim gerçekleştirilmesi planlanmıştır. Çalışma gruplarından tematik analize bağlı mekânsal hafızayı üretirken tematik bir yaklaşımla başlığı metinsel dille vurgulamaları beklenmiştir (Şekil 1).

Bu fazda Henri Lefebvre'ye göre mekânın inşasında algılanan, yaşanan, deneyime bağlı bir kavramsal içeriğin temsil dilinin geliştirilmesi desteklenmiştir. Bağlamsal çerçevesiyle pratiği, temsili ve mekânın kendisi aracılığıyla bir temsili incelemek önem kazanmıştır (Lefebvre ,H., 2014, s.247 ). Böylelikle Lefebvre'nin mekânın inşasını gerçekleştiren toplumsal yapının pratiğini ve iliştiği dönemi anlamak önem kazanmıştır. Bağlamsal olarak imgelemin üretim kaynağı olan Etimesgut ise, bu kapsamda kendine kentsel bir ağ tanımlar. Yapıların, yakın çevresi ile yaya ilişkisinin, yapı ve kullanıcı durumunda ortaya çıkan gündelik alanlar, yeniden üretim sürecini içeren ortaklaşa bir inşa alanı oluşturmaktadır. Bu anlamda Lefebvre'nin tasarlanan mekânı, öğrencilerle gerçekleştirilen kısa süreli problem tanımında parçalayarak incelemeye almıştır. Öğrencilerin bu kapsamda yaklaşımı, içerik analizi dönemsel veri ile örtüşen bir bütünlükte ve çeşitlenen paylaşımları içermiştir. Böylece çalışmanın temsil mekânı, tasarlanan mekandır; yeniden üretimi gerçekleştirilmiş olandır.

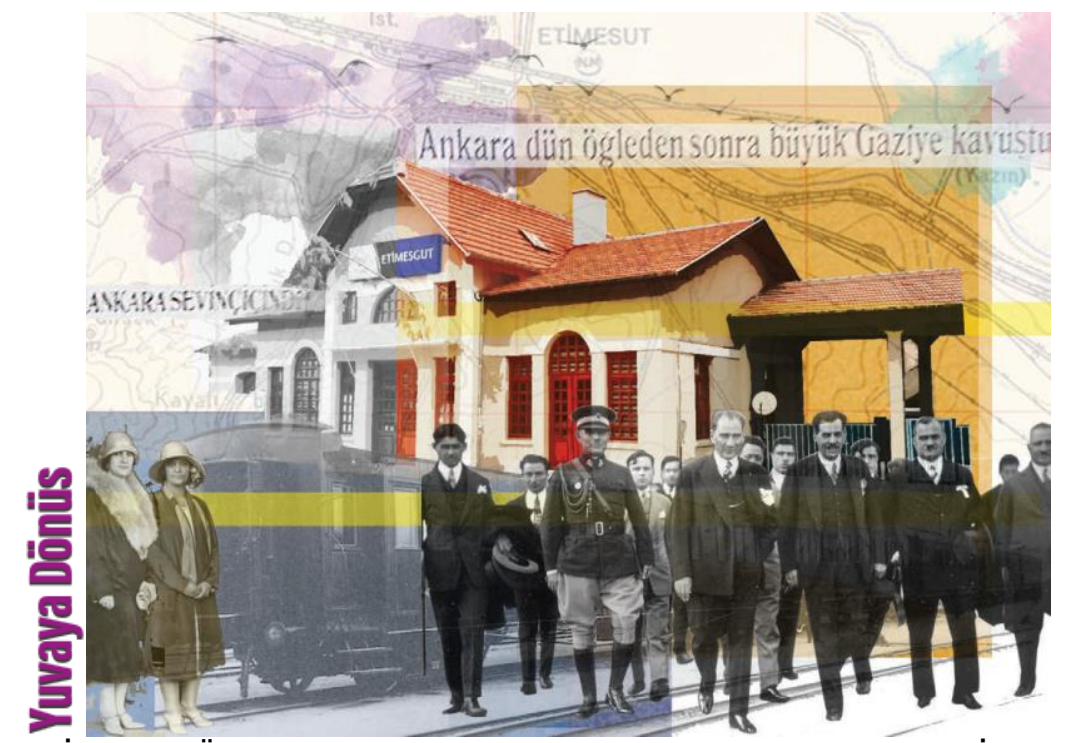

Şekil 1. İmgesel Üretim Çalışması, 'Yuvaya Dönüş: Etimesgut Tren İstasyonu' (Merve Yücel, Duygu Semiz, Şule Koç, 2019.)

Sözlü tanıklıklar ve belgeleme, farklı medyalar aracılığıyla veya temsilleri yoluyla doğrudan veya doğrudan olmayan iki yol ile çalışımıştır. Doğrudan üretim mekânsal deneyim ve mekân kullanıcıları (hafızası) aracılığıyla temsili gerçekleştirilen örüntülerdir. Doğrudan olmayan üretim yolu ise, ikincil veya üçüncül şahıslar tarafından aktarımı gerçekleşen verilerin temsilini içermiştir. Doğrudan olmayan üretim yolu, sosyal tarih, belgesel, edebi kanonda mekânsal aktarım/hafıza, film, fotoğraf, efemera 
(biricik olan) verilerin de değerlendirildiği geri beslemeli bir ilişki tariflemiştir. Tarihsel referansa bağlı imgelem çalışması, eğitimde alternatif bir bilişsel alıştırma olarak yaratıcı sürecin tetikleyicisi konumunda yer almıştır. Hafıza ve bilinç tetikleyicisi olarak sözlü tarih bellek aktarımlarında Kızılay Genel Müdürlüğü, Gar, Şeker Fabrikası ve Yerleşkesi, Japon Gül Bahçesi ve Gülyağı İmalar Tesisleri yoğunluklu olarak anılmıştır. Örnekle, yetmiş üç yaşındaki erkek görüşmecinin belleğinde Etimesgut Şeker Fabrikası, Türk Hava Kurumu Uçak Fabrikası katmanlı bir ilintide ele alınmıştır. Çalışma grubu da özellikle Şeker Fabrikası ve yerleşkesi üzerinden, sosyal içeriği yoğunlaştıııcı bir merkez olarak bölgede çalıştığını tespit etmiş ve belleğini kayıt altına almış, bu katmanlı ifadeyi iki boyutlu temsil diline de aktarmıştır.

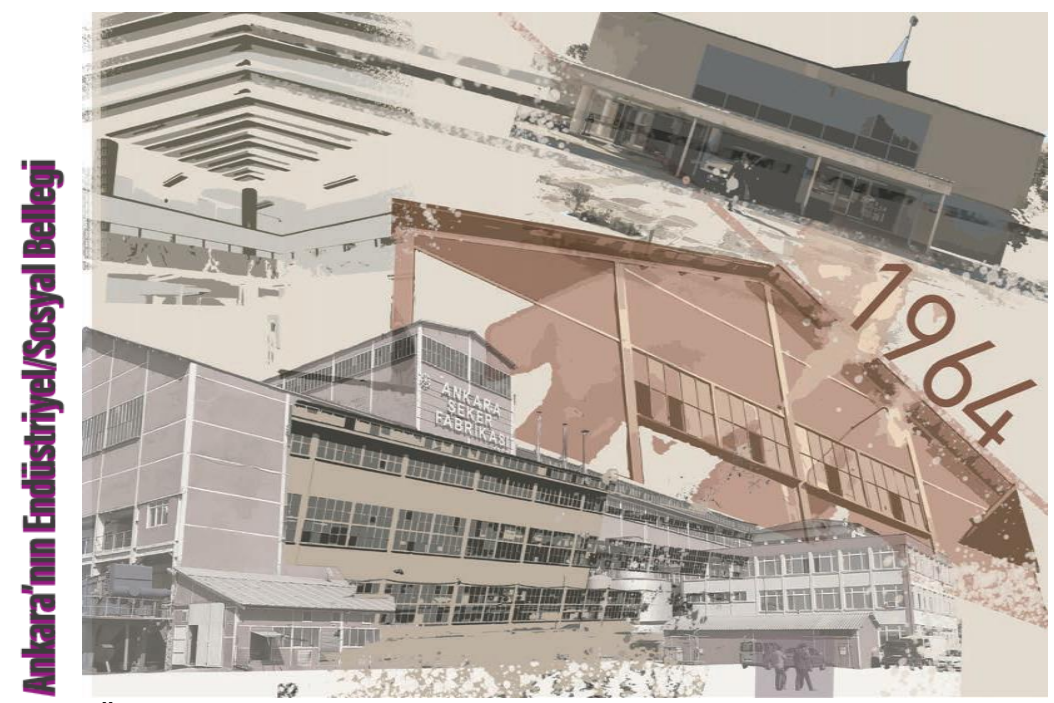

Şekil 2. İmgesel Üretim Çalışması, 'Ankara'nın Endüstriyel/Sosyal Belleği: Şeker Fabrikası Yerleşkesi' (Rüya Öztürk, Batuhan Yeniçeri, Beyza Kulu)

$\mathrm{Bu}$ kapsamda yeniden üretim aşamasında tematik analizlerini, tematik başlıkları 'Ankara'nın Endüstriyel/Sosyal Belleği: Şeker Fabrikası Yerleşkesi' ile oluşturmuşlardır. Görüşmeci bellek aktarımı ise aşağıdaki ifadeyle başlamaktadır (73 Yaşında Erkek Görüşmeci, Yüz yüze görüşme, 2019).

"1948 Yılında Etimesgut'ta doğdum. Illkokul mezunuyum. Taksicilik ve tır şoförlüğü yaptım. Zamanında Türk Kızılay Derneği'nde şoförlük yaptım ve emekliyim. Ailem Bulgar göçmeni ve 1928 yılında Etimesgut'a gelmişler. Ailem göç ettiği zaman köymüş burası, çok az ev varmış...Ev tipi ise tek katlıymıs. Eskiden şehrin merkezine trenle ulaşılırdı ve alışveriş için Saman Pazarı'na giderdik. Burasının eski adı Ahimesgut'tu. Ihtiyaçlarımızı almak için Hal'e çok giderdik. Abim zamanında Uçak Fabrikası'nda on dokuz sene çalıştı. Sonrasında ise orayı Makine Kimya Enstitüsü yaptılar. Şeker Fabrikası'nın inşasına ise 1958 yılında başladılar, 1961 yılında tamamlandı. Fabrika yerleşkesi ufak bir kasaba gibiydi. Lojmanları, eğlence yerleri, sosyal hizmetleri...Lojmanda sadece çalışanlar kalabilirdi. Hatta bir arkadaşımız da vardı...Küçücük odaları, sıkışık ama çok güzel bir yeşil alana bakardı. Kiremit rengidir yapı..."

Bu ifade ve renk kodları iki boyutlu temsil dili dönüştüren ancak süreç içinde irdelenen bir veri bütünü olarak değerlendirilmiştir. Görüşmecilerin belleğinde yer alan bir diğer mekânsal yaklaşım örneği olarak Kızılay Genel Müdürlüğü ve Depoları, özellikle faal olarak kente ve kentlilere çok yönlü olarak hizmet eden yerleşke olarak ifade 
bulmuştur. Görüşmecilerin özellikle savaş ekonomisine ilişkin aktarımlarında yiyecek ve giyecek yardımı, kutlama gelenekleri ön plana çıkarken çalışma grubu envanter ve bireysel arşiv üzerinden elde edilen belgeler ile iki boyutlu bir temsil dili üretmiştir (Şekil 2).

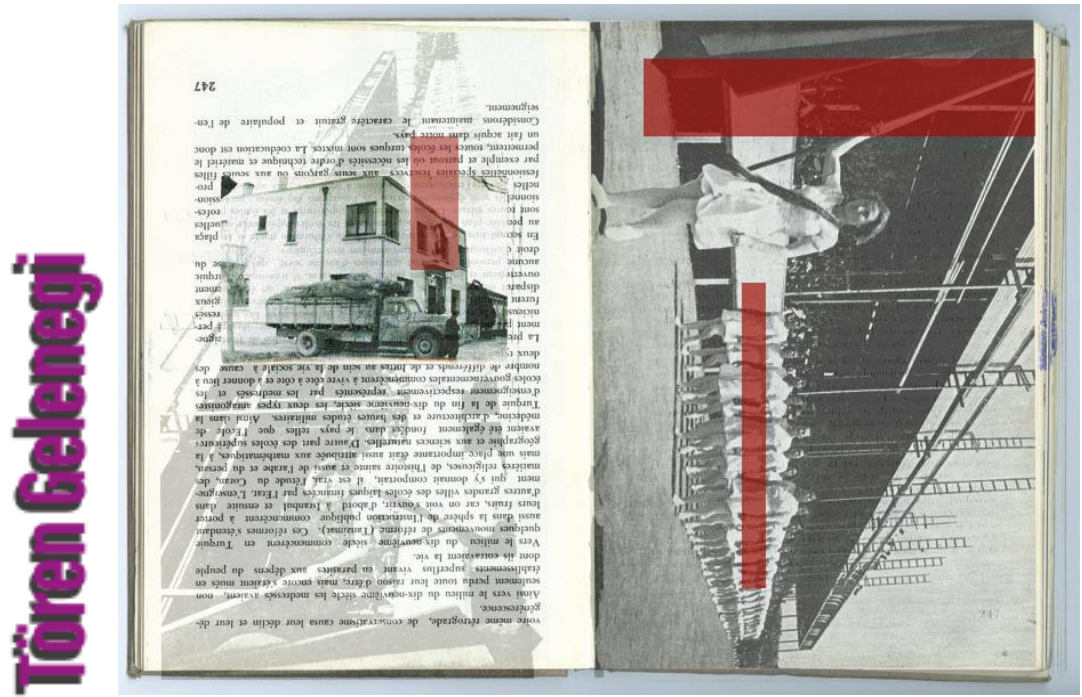

Şekil 3. İmgesel Üretim Çalışması, ‘Kızılay Genel Müdürlüğü Yerleşkesi: Tören Geleneği' (Gülce Bıyıklı, Zozan Özdemir, Onur Görüroğlu)

Millileşen bir ekonominin açılımı olarak Etimesgut Türk Hava Kurumu Uçak Fabrikası kentte ve bölgesel olarak Etimesgut'ta önemli bir mekânsal tanım getirmektedir. Görüşmecilerin aktarımında yer almakta olan millileşen üretim teknolojileri ön plana çıkmakta ve havacılık sanayiinde yer alan çok sayıda üçüncü şahısa değinilmiştir. İlk yerli uçak üretiminin gerçekleştiği Fabrika, 1960'lı yıllar itibarıyla üretim alanını değiştirmiştir; ancak halkın bir toplanma ve izleme eylemi bir kutlama faaliyeti ile belirtilen yıla kadar sürdürülmüş ve hafıza öğeleriyle aktarılmıştır (Şekil 4).

Görüşmeci belleğinde yer alan ve kesişen, ortaklaşan hikâyelerin aktarımında mekânsal aktörlerin deşifresini gerçekleştiren grup çalışmasında odak grubun hikâyeleri, imgeleri katmanlı bir ifadeyle kompoze edilmiş bu yolla belleğin katmanlı yapısı aktarılmıştır (Şekil 5).

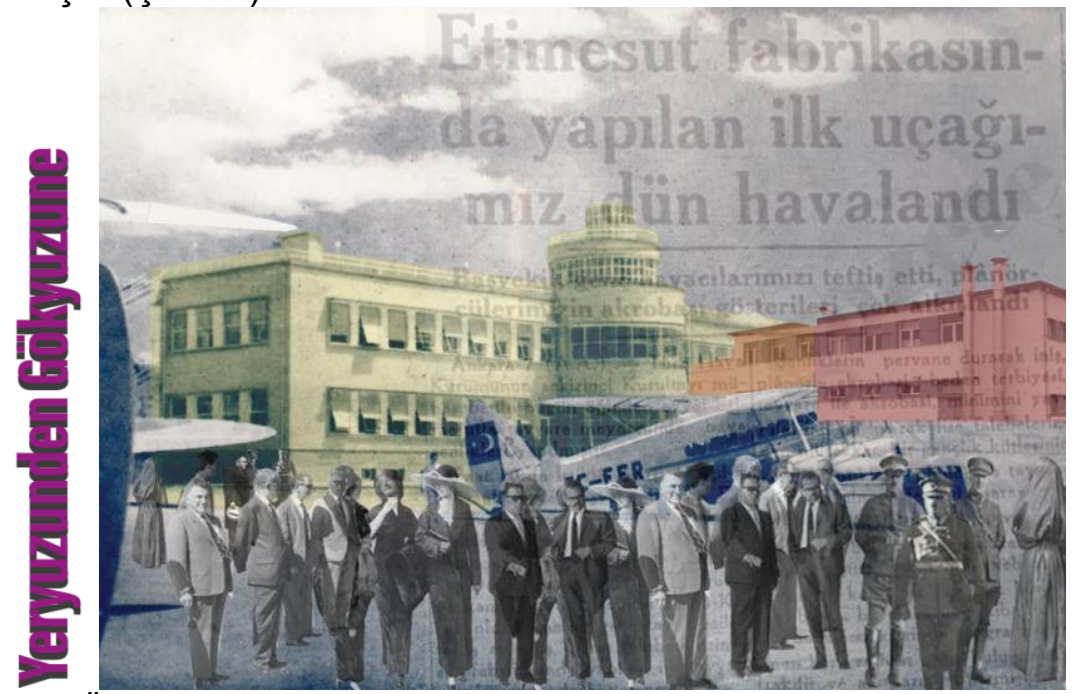

Şekil 4. İmgesel Üretim Çalışması, 'Yeryüzünden Gökyüzüne: Etimesgut, Türk Hava Kurumu Uçak Fabrikası' (Ece AKSOY, Feyza SALAŞ, Burcu GÜMÜŞ, Gözde EKINCIOĞLU, 2019.) 
Öğrencilerin yazılı ve sözel kaynakları değerlendirme aşamasında gerçekleştirilen bu çalışma, bir arkeolojik kazı alanı analojisi ile irdelenmiştir (Reed, S., P., 1982, s.32). Yürütücü tarafından sözlü tarih metodolojisi kapsamında bu aşamanın kendisine ilişkin 'bilgiyi doğrulama' gereksinimi aktarımış, metodun kendisinde yer alan yorumlama, odak anlatısı fazı çalışma öncesinde tartışıımıştır.

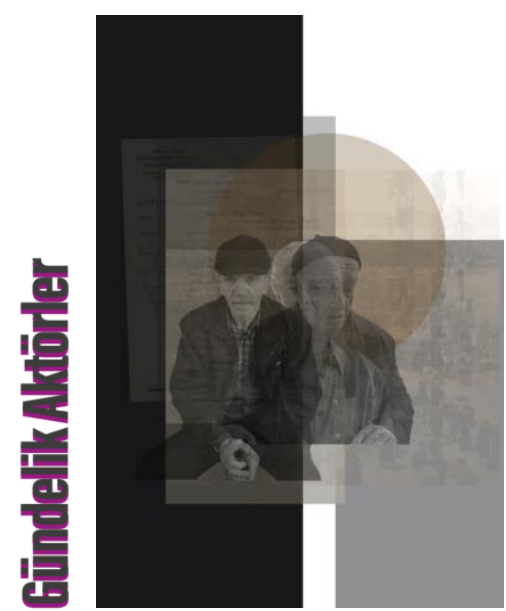

Şekil 5. İmgesel Üretim Çalışması, 'Sözlü Tanıklık ile Gündelik Aktörler' (Elif YAZıCI, Duhan AYLA, Elif ALIBBEKIROGLU, Sarp Arman ÇITLAK, Sude Cansın SABUNCU, 2019.)

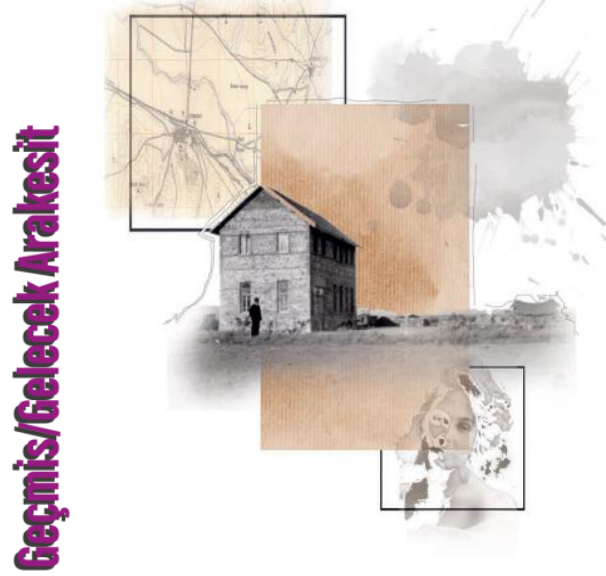

Şekil 6. İmgesel Üretim Çalışması, ‘Etimesgut Japon Gül Bahçesi ve Gülyağı İmalat Tesisleri: Geçmiş ve Gelecek Ara Kesiti' (Gamze YAZICI, Yağmur ÜNLÜ, 2019.)

Seçili çalışmalar, mekânsal okuma ve yeniden üretim pratikleri, verilerin incelenmesi aracılığıyla kısa süreli problem çözme pratiğinde yaratıcılığı tetiklemiştir (Ed. Öymen Gür, Ş.; Gür,B., 2017, s.49). Bu çalışmanın sorunsalını oluşturan temsil meselesi farklı bir çalışmanın tartışması olarak yer alabilir ancak, yaratıcı süreç odaklı bir yaklaşımın varlığı ile (Küçüktaşdemir, Güliz; 2018, s.367) yeni eylem yaklaşımlarını kendi içinde üretmiştir.

\section{Kuramsal Tartışma Temelli Üretim}

Dersin ana strüktürünü oluşturan üç teorik yapılanma içerisinde kuramsal tartışmanın yeniden üretimi fazı, bir 'eleştirel bakışla' bütüncül sürecin aktarım aşamasını içemiştir. Paul Freire'nin tariflemekte olduğu eleştiri dili, eğitimin özgürleştiricisi olarak yeni olasılıkları barındırmaktadır. Bu kapsamda Freire, Marksist bakışla praksisin, yaratıcı üretim biçiminin sunulan sınırları aşarak gerçekleşebileceğini öngörmekte, teori ve 
uygulamalı alanlarda özellikle eşzamanlı bir geri bildirime değinmektedir (Freire, P., 2008, s.72). Tarih yazımının kendisi gibi eğitimin tarafsız olamayacağı savı Freire tarafından vurgulanmaktadır. Süreç içinde yoğurulan, evirilen, özgürleşen bir alan intiyacına işaret etmektedir. Freire'nin yaklaşımına göre eğitimde öğrencilere dogmatik bilgiye sunan yaklaşımlar 'bankacı modeli' olarak adlandırılmıştır. Tarihsel şartlara bağlı oluşuturulmuş içerikten arındırımış, mutlak bilgi olarak sunulan bilgi kümesini içermekte ve öğrenci konumundaki kişilere 'ezilen bilinci' dayatması sağlamıştır (2008).

$\mathrm{Bu}$ anlamda problem tanımlayıcı eğitim modeli yaklaşımıyla düşünme eyleminden uzaklaşılmadan içerik oluşturulması iç mimarlık eğitimi için önemli bir hedef haline gelmiş araştırmanın bu fazında 'özgürleştirici bir tartışma ortamı' sunulmuştur. Çalışmanın öncül aşamalarında oluşturulan sorgulamalı içerik bir bütün olarak yer almaktadır. Grup çalışması aracılığıyla tamamlanmış olan çalışmayı takiben kuramsal bir tartışma gerçekleştirilmiş, dönem okuması, resmi/resmi olmayan kaynakların incelemesi, sözlü tarih deşifre belgeleri, bellek mekanlarının imgesel üretim yaklaşımları çoğul yönlü olarak ele alınmıştır. Ek olarak bağlamsal olarak Ankara, dönemin mimarlık ortam pratiğine ait paylaşımda bulunulmuş, sürece ilişkin gözlemler tartışılmıştır. Tüm bunlara ek olarak kuram temelli tartışmanın temsilinin, çalışma gruplarının üretimi kapsamında değiştirilebileceği belirtilmiştir. Ancak, öğrenci grubuna ait paftaların birbiri ile ilişkili ve dil bütünlüğünde ele alınma gereksinimi vurgulanmış, tartışmanın metinsel aktarımının sağlanması beklenmiştir.

Disiplinler üstü bir başlık olarak tasarım disiplini, kadın çalışmaları, evrensel tasarım, kültürel anlam ve bellek çalışmalarının eğitimi derinlik kazandıran yönü bu yolla öğrencilerle deneyimlenmiştir. Sözlü tarih metodolojisi ve belgeleme, geçmiş haritalarını aktaran ve sosyal tarihin mekânsal uzantılarını saptayan araçlar olarak yer almış, mekânı okuma ve yeniden üretme pratiğinin potansiyellerini artıımıştır. Bütüncül eğitim sisteminde görünmez kılınan 'sosyo-mekansal tarih' eğitimciyi, öğrenciyi ve potansiyel uygulamacıları bu araştırma kapsamında dâhil etmiş, yaratıcı düşünce biçimini geliştiren olası katkıları barındırmıştır.

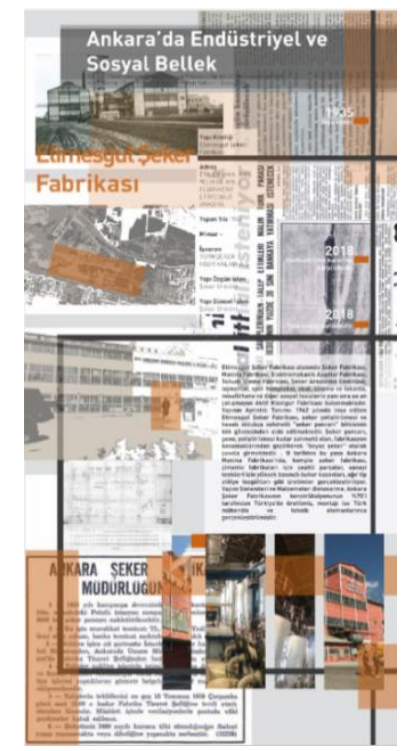

Şekil 7. Sergi paftası, Rüya Öztürk, Batuhan Yeniçeri, Beyza Kulu 


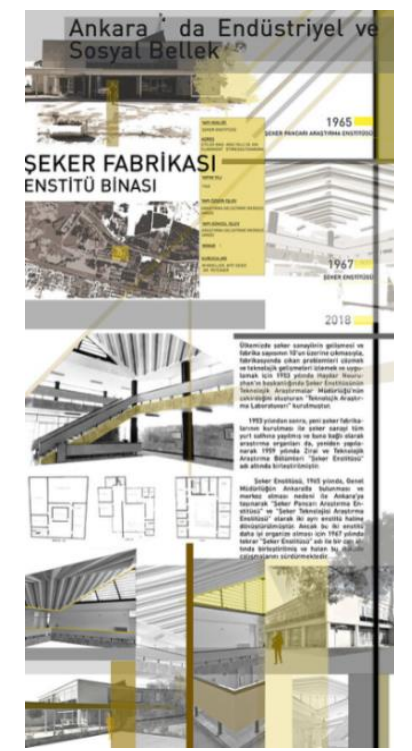

Şekil 8. Sergi paftası, Rüya Öztürk, Batuhan Yeniçeri, Beyza Kulu

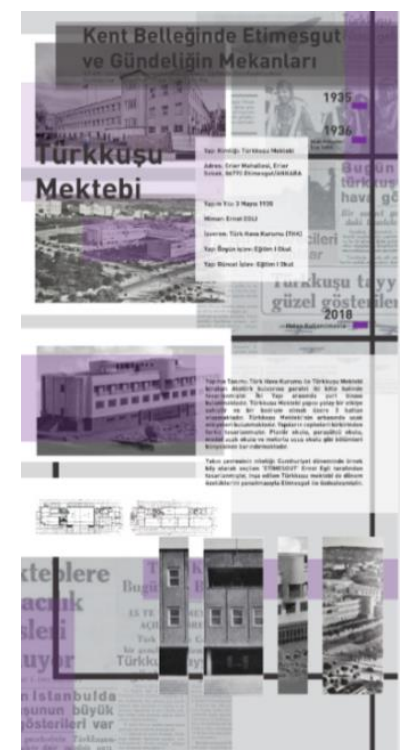

Şekil 9. Sergi paftası, Merve Yücel, Duygu Semiz, Şule Koç

Özellikle öğrenci yaklaşımlarında bu aşamanın ayrışan yönleriyle metinsel ifade aktarımı gerçekleştirildiği gözlemlenmiştir. Bütüncül veri ile hikâye oluşturma ve bağlamsal çerçeveye ilişkin eleştirel bir gözlem aktarımı yer almıştır. Sırasıyla sosyal bellek içeriği ile Şeker Fabrikası Yerleşkesi değerlendirilmiş, kadın görüşmecilerin gündelik yaşam katılımları konusuna 'görünürlük' bakımından eleştirel bir bakış geliştirilmiştir (Şekil 7-8). Yerleşke içinde enstitü çalışanlarının da konaklamakta olduğu lojman yaşantısı ve gündelik ihtiyaçlara ait kent içerisindeki hareket etme durumu özellikle vurgulanmıştır. Böylece fiziki olarak mekân bir yapısal incelemeye tabi tutulmuştur. 


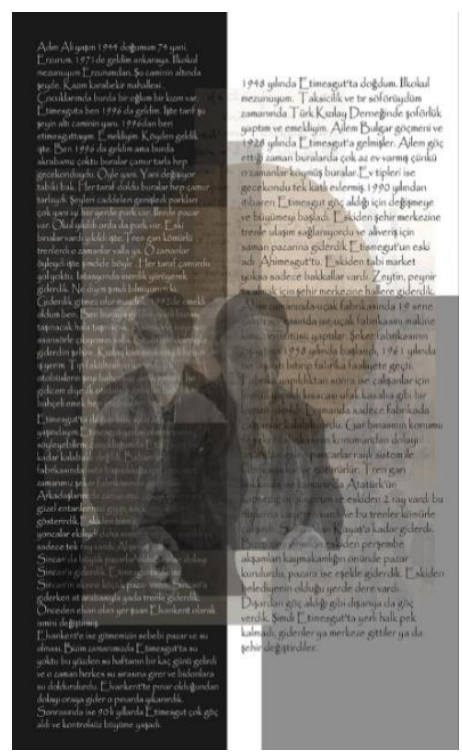

Şekil 10. Sergi paftası,Elif Yazıcı, Duhan Ayla, Elif Alibekiroğlu, Sarp Arman Çıtlak, Sude Cansın Sabuncu Çalışmaları

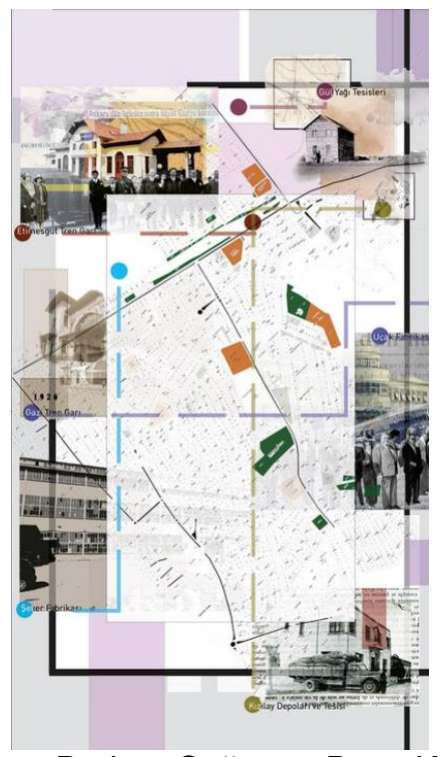

Şekil 11. Sergi paftası,Berkan Çağman, Buse Kozan, Ozan Kalkan

Türkkuşu Mektebi, Bölgenin endüstriyel kimliğini yoğunlaştırmakta olan çalışan nüfusunu barındırmaktadır. Bu bağlamda öğrenciler, çalışan yakınları, çalışma koşulları ve üretim pratikleri hakkında bilgi edinmiştir. Dönem işçileri bölge içinde hareketini yürüme eylemi veya traktör gibi araçlarla gerçekleştirmektedir (Şekil 9). Bu hareketlilik ise bir ağ aracılığıyla haritalandırma ve kentsel yön bulma amacı taşımıştır (Şekil 11). Böylece öğrenci gruplarının ortaklaşan çalışması ortak bir tema bağlamında yeni çalışmaları da içerisinde barındıran üretken bir süreci içermiştir.

\section{Sonuç ve Değerlendirme}

İç mimarlık eğitiminde yaratıcı düşünme becerisi, en temel yaklaşımla iki temel yol ile geliştirilmektedir. Bu gerçekleşme biçimi kuramsal ve uygulama merkezli ders içerikleri ile ortaklaşan/ayrışan müfredat yaklaşımları tanımlamaktadır. Bu anlamda 'biçimsel' yaklaşım, kavramsal arayış sürecinde eğitim özgürleştiricisi olarak sözlü tarih 
aktarımından beslenen yeni bir süreç tanımlayabilir. Bu yolla da metaforik veya doğrudan analoji ile kurgulanabilir.

Böylelikle sözlü tarih ve belgeleme metodolojisi, bir yeniden üretim pratiği olarak, kuram ve uygulama merkezli derslerin enstrümanı olarak yer alabilir. Dönemsel söylem ve sosyal normlar, kavramsal oluşumları da destekleyebilir.

İmgelem ve sezgisel yanı ile de sözlü tarih, sosyal deneyim ile teması arttırabilme potansiyelini sunmaktadır. Karl Marx'a göre yaratıcı düşüncenin gücü, entelektüel bir üretimin kaynağı, yaratıcı bir estetik üretiminin ön koşulu olarak rasyonel gelişimi desteklemektedir (Philip, K., 1988, s.294-312). Bu rasyonel gelişim, kuram temelli ders içerikleri ile aşağıdaki maddeler aracılığıyla deneyimlenebilir.

- İç mekân, sosyo-mekansal tarih üzerinden okunurluğu arttırılan mekân bir nesne olarak tarihsel içeriği öğrencilere sunar, zamansız bir aktarıma kavuşmuş olur.

- Güncel-geçmiş zaman dilimi ile karşılaştırmalı okuma sağlanabilir, yok olanlar saptanabilir.

- Makro ölçekli bir tarihsel okuma yerine mikro ölçekli bir ölçek üzerinden alternatif anlatıyı, kronolojik sıralama odak grubu ile sunulabilir.

- Mekânsal tarih ve metinsel temsil ilişkisi kurulabilir; dilsel bağlantının gelişimi ve mesleki jargonun gelişimi desteklenebilir.

- Yürütücü ve öğrenci için eş zamanlı üretme, sorgulama potansiyeli bulunabilir. $\mathrm{Bu}$ anlamda bu yöntem aracılığıyla, 'problem tanımı' önceden planlanmadan sürecin bir ürünü olarak eş zamanlı üreyebilir.

Bu çalışma aracılığıyla kuram temelli ders içeriklerinde sözlü tarih bağlantısı ile tarihsel arka plan ilişkisinin kurulabileceği, üretim biçimleri bakımından olumlu sonuçlar oluşturabileceği savı üzerinde durulabilir. Yeni temsil araçlarının üretilmesi için bir araç olarak değerlendirilebilir. Bunlarla birlikte, bu kuramsal temelin uygulamalı ders içerikleri ile kurmakta olduğu yeni üretim biçimi, birey/grup üretim dinamiğini de dönüştürebilir.

$\mathrm{Bu}$ çalışma, ilerleyen çalışmalar için metodolojik bir düşünce biçiminin iç mimarlık eğitimi üzerine potansiyel yararlarını ortaya koymakta ve tartışmaya açmaktadır. Böylelikle iç mimarlık eğitiminde yaratıcılık, sözlü tarih metodolojisi ve belgeleme aracılığıyla, mekânı okumak ve yeniden üretmek kapsamındaki anlam çalışmasında 'güçlü' bir araca dönüşebileceği sonucuna varılmıştır. 'Yaratıcı' düşünme biçimini destekleyecek bu aracın gücü ise, bilinmeyen problemin tanımı, sosyal-kültürel temas, hafızaya dayalı üretimin doğasını keşfetmeye dayalı bilişsel bir sürece işaret etmiştir.

Bu çalışmanın sonunda,

- Uygulamalı süreç içinde öğrenci, gerçek kişi ve mekânsal ilişki ağı ile 'yer' den üreyen sosyal mekân duyarlıığını geliştirmiştir.

- Kullanıcı ve mekân ilişkisini çoklu veri ile saptayabilme becerisini arttırmış (sosyo-psikolojik etkisi, kültürel veriler aracılığıyla), yeni üretim medyalarını test etmiştir.

Dilsel ve anlama ilişkin çalışmalarda tarih yazımı alt okumalarının oluşturulması, hafızanın değiştirilebilmesi anlamında yapısal bir alan tanımlayabilir.

Böylelikle de iç mimarlık eğitimi içinde sözlü tarih metodu, yeni bir teorik bakışla mesleki dil ve pratiğe etki etki edecek yaratıcı sürecin tetikleyicisi olabilir. Bu çalışma ve 
İç Mimarlık Eğitiminde Sözlü Tarih Yöntemi ve Belgelemeyi Bir Mekân Okuma, Yeniden Üretim Pratiği Olarak Değerlendirme

üretilen veriler, ilerleyen çalışmalar için yeni bir araştırma alanı için yöntem ve problem tanımında yer alabilir.

\section{Kaynaklar}

3.Sanat ve Tasarım Eğitimi Sempozyumu ve Çalıştayı Bildiriler Kitabı; Dijital Çağda Sanat ve Tasarım, 19-20-21 Aralık 2018, Küçüktaşdemir, G., Kimlik Meselesi Olarak İç Mimarlık Eğitiminde (Dijital) temsil: Deneysel Bir Stüdyo Çalışması, s.367; Başkent Üniversitesi, Ankara: Mim İç ve Dış Mekân Baskı Sistemleri Rek. Matbaacılık Tic. Ltd. Şti.

Angél I, Marc. Inchoate: An Experiment in Architectural Education. Zür ch: E dgenöss sche Techn sche Hochschule, 2003.

Arendt, Hannah. The Human Condition. Chicago: University of Chicago Press, 1998.

Kain, Philip J. Marx and Ethics. Oxford: Clarendon Press, 1988.

Marx, Karl, and David Fernbach. Capital: : a Critique of Political Economy. , 1991.

Öymen, Gür S. M mar Tasarım Eğt m ne Çağdaş Önermeler., Istanbul, Turkey : Kolektif YEM Yayınevi, 2017.

Perks, Robert, and Alistair Thomson. The Oral History Reader. London: Routledge, 1998.

Philip Kain, Marx and Ethics, Oxford: Clarendon Press, 1988, 15-82.

Sargın, Güven Arif, Toplumbilim Açısından Mimari Praxis: Mimarlığın Öteki Ayraçları Üzerine Düşünceler. "Mimarlık", 2005, s.22-25.

Weinthal, Lois. Toward a New Interior: An Anthology of Interior Design Theory. New York: Princeton Architectural Press, 2011.

Rice, C. (2007). The emergence of the interior: Architecture, modernity, domesticity. London: Routledge. | Irrecoverable Inhabitants

Freıre, Paulo. Ezilenlerin Pedagojisi, Çev. Dilek Hattatoğlu-Erol Özbek, Ayrıntı Yayınları, İstanbul, 2008.

Thompson, Paul R. The Voice of the Past: Oral History. Oxford: Oxford University Press, 1988.

Formun Altı

Perks, Robert, and Alistair Thomson. The Oral History Reader, 2016.

Formun Altı

Marx, Karl, Friedrich Engels, Ernest Mandel, David Fernbach, and Karl Marx. Capital: A Critique of Political Economy. London: Penguin Books in association with New Left Review, 1991.

Formun Üstü 
Creswell, John W. Qualitative Inquiry \& Research Design: Choosing Among Five Approaches. Loa Angeles: Sage, 2013. Print.

Lefebvre, Henri. The Production of Space. Oxford, OX, UK: Blackwell, 1991.

Nevins, Allan. "The Uses of Oral History." In Oral History at Arrowhead: The Proceedings of the First National Colloquium on Oral History, 1966. Elizabeth I. Dixon and James V. Mink, eds. Los Angeles, The Oral History Association, 1967

Kitzingir, J. The Methodology of focus group: the importance of interactions between research participants. Sociology of Health and IIIness,1994.

Riessman, Catherine K. Narrative Analysis. Newbury Park, CA: Sage Publications, 1993. 